\title{
PRICE TRANSMISSION ANALYSIS IN PORK SUPPLY CHAIN IN SERBIA
}

Marija Jeremić ${ }^{1}$, Stanislav Zekić2 ${ }^{2}$ Bojan Matkovski ${ }^{3}$, Danilo Đokić ${ }^{4}$, Žana Jurjevićs

*Corresponding authorE-mail: bojan.matkovski@ef.uns.ac.rs

\begin{tabular}{ll} 
A R T I C L E I N F O & A B S T R A C T \\
Original Article & $\begin{array}{l}\text { As the pork supply chain was perceived through three level } \\
\text { of chain: agricultural sector, processing and distribution } \\
\text { sector, the main objective of this paper was the estimation } \\
\text { of the vertical price transmission in the pork supply chain in } \\
\text { the Republic of Serbia for period 2008-2015. The analysis }\end{array}$ \\
Accepted: 27 April 2020 & $\begin{array}{l}\text { of the price transmission was related on the presence of } \\
\text { the asymmetry and was estimated with AECM model. The }\end{array}$ \\
UDC 338.51:637.5'64(497.11) & $\begin{array}{l}\text { results indicated the presence of the negative asymmetry } \\
\text { in the price transmission and one of the main causes of the } \\
\text { presence of asymmetry was the abuse of the market power } \\
\text { by processing sector, i.e. slaughtering industry. }\end{array}$ \\
\hline $\begin{array}{l}\text { Pork, Chain, Transmission, } \\
\text { Asymmetry }\end{array}$ &
\end{tabular}

JEL: $Q 13, C 22$

(C) 2020 EA. All rights reserved.

\section{Introduction}

In the 1990s, the food supply chain went through significant changes. One of the most pronounced changes occurred in the meat supply chain. Namely, the most important changes happened in the meat processing and retail sectors. Those changes are related to the growth of concentration of this sectors. The growth of concentration of the processing and distribution sector has caused their market dominance in relation to

1 Marija Jeremić, Ph.D, Assistant Professor, University of Novi Sad, Faculty of Economics in Subotica, Segedinski put no. 9-11, 24000 Subotica, Republic of Serbia, Phone +381 24628 065, E-mail: knezevicm@ef.uns.ac.rs, ORCID ID (https://0000-0002-5748-4005)

2 Stanislav Zekić, Ph.D, Full Professor, University of Novi Sad, Faculty of Economics in Subotica, Segedinski put no. 9-11, 24000 Subotica, Republic of Serbia, Phone +381 21485 2923,E-mail: zekics@ef.uns.ac.rs. ORCID: 0000-0003-3872-1332

3 Bojan Matkovski, Ph.D, Assistant Professor, University of Novi Sad, Faculty of Economics in Subotica, Segedinski put no. 9-11, 24000 Subotica, Republic of Serbia, Phone +381 24 628 049, E-mail: bojan.matkovski@ef.uns.ac.rs. ORCID: 0000-0003-2563-3843

4 Danilo Đokić, Ms.C, Teaching Assistant, University of Novi Sad, Faculty of Economics in Subotica, Segedinski put no. 9-11, 24000 Subotica, Republic of Serbia, Phone +381 24628 049, E-mail: danilo.djokic@ef.uns.ac.rs. ORCID: 0000-0002-7962-4910

5 Žana Jurjević, Ms.C, Teaching Assistant, University of Novi Sad, Faculty of Economics in Subotica, Segedinski put no. 9-11, 24000 Subotica, Republic of Serbia, Phone +381 24628 046, E-mail: zana.kleut@ef.uns.ac.rs. ORCID: 0000-0002-3809-7923 
agricultural producers. Accordng to Pjanić et al. (2018), increases in the concentration of the power of the individual market participants usualy results in limiting the market power of other power participants“. The market power abuse resulted in an uneven distribution of profits among the participants in the supply chain (Coleman et al., 2004; OECD, 2006). One of the ways to analyze structural changes that have occurred in the food supply chain is price transmission analysis along the food supply chain, as an important phenomenon that describes the overall functioning of the market. The changes that have taken place along all the participants of the supply chain point to the necessity of examining the formation and way of transferring prices along the food supply chain. Also, the examination of the vertical price transmission can be used as an indicator of inefficiency of the chain, and as an indicator of the degree of competitiveness within the chain itself (Blažková and Syrovátka, 2012). For better understanding of the price transmission analysis results it is important to identify factors that influence on the market. There are many factors that determine situation on the agricultural markets, but structure of the market participants and institutional framework are the most important. Also, actual process of foreign integration significantly can influence on prices of agrifood products as this process is followed by the liberalization of market, so it can pose a serious competitive threat to domestic producers (Nestorov-Bizonj et al., 2015).

Pig farming is a significant branch of agriculture in Serbia. According to the share in the total value of agricultural production, pig farming is the second most important branch of livestock production in Serbia. According to Jeremic et al. (2016), pork is the most consumed (28 kg per capita per year) and most produced meat, from 2000 to 2014 in Serbia, share of pork in total meat production was $58 \%$. Therefore, having in mind changes that occurred in meat supply chain, as well as importance of pork production for Serbian agriculture, the focus of this paper is on the price transmission in the pork supply chain.

The vertical price transmission in the pork ${ }^{6}$ supply chain has so far been analyzed by a large number of authors, and some of them are Boyd and Brorsen (1988), Purcell (1999), Goodwin and Harper (2000), Abdulai (2002), Backus and Fertö (2005), Jensen and Møller (2007), Čechura and Šobrova (2008), Karntininis et al. (2011), Rumánková (2012) and Djurić and Petković (2013). Also, a numerous authors analysed spatial price transmission in pork market such as Sanjuán and Gil (1998), Meyer (2004), Liu (2011), Holst and Von Cramon Taubadel (2014), Djuric and Puskaric (2015). The main objective of the paper was to idenetify the nature of the price transmission along the pork supply chain in the Republic of Serbia, and the presence of (a)symmetry is tested. Also, the aim of the paper was to identify the factors that influence the presence of asymmetry in the chain with the focus on the market structure of the participants. In accordance with the aim of the paper, appropriate econometric methods have been

6 In this paper, only fresh meat was considered. According to Ecroys (2010), fresh meat is meat that has not undergone any processing process, except cooling, freezing and quick freezing. More precisely, the work did not analyze leather, fats, edible and inedible waste or pork products. 
selected and applied. The paper consists of the following section: first, the theoretical framework of the model used for price transmission analysis was defined. Afterwards the pork supply chain in Serbia was explained and the model was estimated. In the last section of the paper final conclusion are given and ideas for future research.

\section{Materials and methods}

An Asymmetric Error Correction Model (AECM) was used to assess the presence of asymmetry in pork supply chain. AECM model was created as a result of the improvement of the methodology previously used for the analysis of asymmetry. Namely, first model that was used was developed by Wolffram (1971), which, afterwards, modified Houck (1977):

$\Delta \mathrm{p}_{\mathrm{t}}^{\text {out }}=\gamma_{0}+\gamma_{1}^{+} \mathrm{D}_{\mathrm{t}}^{+} \Delta \mathrm{p}_{\mathrm{t}}^{\text {in }}+\gamma_{1}^{-} \mathrm{D}_{\mathrm{t}}^{-} \Delta \mathrm{p}_{\mathrm{t}}^{\text {in }}+\mathrm{u}_{\mathrm{t}}$

where $\mathrm{p}^{\text {out }}{ }_{\mathrm{t}} \mathrm{i} \mathrm{p}^{\text {in }}{ }_{\mathrm{t}}$ represents prices of output and input respectively, $\Delta$ indicates on first

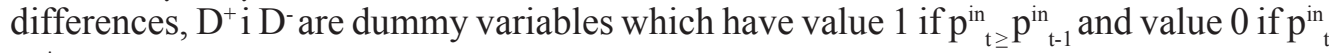
${ }_{\leq} \mathrm{p}_{\mathrm{t}-1,1}^{\text {in }}$ and $\gamma_{0}, \gamma^{+}, \gamma^{-}$are parameters. Using the equation 1 zero and alternative hypothesis are estimated. Namely, zero hypothesis, $\mathrm{H}_{0}$, tests symmetrical price transmission $\left(\mathrm{H}_{0}\right.$ : $\gamma^{+}=\gamma^{-}$). On the other hand, an alternative hypothesis, $\mathrm{H}_{1}$, tests asymmetry of price transmission $\left(\mathrm{H}_{0}: \gamma^{+} \neq \gamma^{-}\right)$.

According to Ward (1982) equation (1) had some limitation which was overcome with by including lags of exogenous variables.

$\Delta \mathrm{p}_{\mathrm{t}}^{\text {out }}=\gamma_{0}+\sum_{\mathrm{j}=1}^{\mathrm{M}}\left(\mathrm{y}_{1}^{+} \mathrm{D}_{\mathrm{t}}^{+} \Delta \mathrm{p}_{\mathrm{t}-\mathrm{j}+1}^{\mathrm{in}}\right)+\sum_{\mathrm{j}=1}^{\mathrm{N}}\left(\mathrm{y}_{1}^{-} \mathrm{D}_{\mathrm{t}}^{-} \Delta \mathrm{p}_{\mathrm{t}-\mathrm{j}+1}^{\mathrm{in}}\right)$

Equation (2) developed by Wolfram also had some shortage. Namely, in the equation (2) problems arising from using nonstationary data were not considered. Von CramonTaubadel (1998) suggested modification of equation (2) by including the concept of cointegration in it.

$p_{t}^{\text {out }}=\beta_{0}+\beta_{1} p_{t}^{\text {in }}+u_{t} p_{t}^{\text {out }}=\beta_{0}+\beta_{1} p_{t}^{\text {in }}+u_{t}$

If the estimation of the equation (3) indicates that there is no false regression, that is if indicates that variables are cointegrated, the application of the AECM model is justified, and the model has the following form:

$\Delta \mathrm{p}_{\mathrm{t}}^{\text {out }}=\gamma_{0}+\sum_{\mathrm{j}=1}^{\mathrm{M}}\left(\mathrm{y}_{1}^{+} \mathrm{D}_{\mathrm{t}}^{+} \Delta \mathrm{p}_{\mathrm{t}-\mathrm{j}+1}^{\text {in }}\right)+\sum_{\mathrm{j}=1}^{\mathrm{N}}\left(\mathrm{y}_{1}^{-} \mathrm{D}_{\mathrm{t}}^{-} \Delta \mathrm{p}_{\mathrm{t}-\mathrm{j}+1}^{\mathrm{in}}\right)+\psi^{+} \mathrm{u}_{\mathrm{t}-1}^{+}+\psi^{-} \mathrm{u}_{\mathrm{t}-1}^{-}+\varepsilon_{\mathrm{t}}$

After the specification, model is estimated by using the ordinary least square method and testing the hypothesis of the presence of asymmetry in the transmission of prices, for short and long term. Namely, using the Wald test, the following zero hypotheses are tested: 
- $\mathrm{H}_{01}: \gamma^{+}=\gamma^{-}$the zero hypothesis of the presence of long-term symmetry.

- $\mathrm{H}_{02}:{\beta^{+}}_{1 \mathrm{i}}=\beta^{-}$, the zero hypothesis of the presence of symmetry in a short term between the prices of the processing sector and the agriculture sector.

- $\mathrm{H}_{03}: \beta_{2 \mathrm{i}}^{+}=\beta_{2 \mathrm{i}}^{-}$, the zero hypothesis on the presence of symmetry on the short term between the retail and agricultural sectors.

In order to assess the vertical price transmission in the pork supply chain, data on monthly prices were used for the following participants of the supply chain: the agricultural sector (data on prices of fattening pigs), the processing sector (data on prices of pig carcases) and the retail sector (data on pork meat prices). Price data refer to the period from May 2008 to December 2015. Prices for all participants of the chain are expressed in euro per kilogram. The data used are shown in Figure 3. As data sources, the following were used ${ }^{7}$ :

- Monthly statistical bulletins for data on prices of fattening pigs and for data on monthly retail prices of pork.

- Data from the GEA Centre on prices of pig carcases.

- OANDA database for data on the average monthly exchange rate.

\section{Results and discussions}

\section{The pork supply chain}

The pork supply chain in Serbia was perceived three participants: the agricultural sector, the processing and distribution sector. The agriculture sector, as the first participant of the pork supply chain, was observed on the basis of pig farms in Serbia. In Serbia, there are about 3.5 million pigs and 355 thousand pig farms (SORS, 2017). An analysis of the characteristics of the pig sector indicated that small family farms are the most important category of agricultural holdings in Serbia (Figure 1.). Namely, according to the realized value of the standard output, $80.4 \%$ of the pig farms in Serbia belong to the category of small farms ${ }^{8}$, and in their possession there are $41.4 \%$ of all pigs. The following are medium-sized farms, which account for $18.6 \%$ and hold $31.1 \%$ of all pigs. On large farms that make up only $0.96 \%$ of the total number of farms, $27.5 \%$ of the pigs are raised. In other words, small-sized and medium-sized farms are the most numerous and have the largest number of pigs in their ownership. That means that the production of pigs and pork is mostly determined by the production trends on these farms. As the agricultural sector are concerned, there is a disunity of supply due to the presence of a large number of small agricultural producers who by their own production are unable to meet the needs of the slaughter industry. As market structure is concerned, agricultural sector, i.e. pig farms, represents competitive market.

7 For the estimation of the models Eviews 8.1. were used.

8 The criterion for pig farms size classification is based on Popovic (2014): small sized farm is farm with less than 8,000 euro, medium sized farm is farm with 8-25,000 euro, and large farms include farms with more than 25,000 euro of standard output. 
Figure 1. The size of pig farms in Serbia (000 euro standard output)

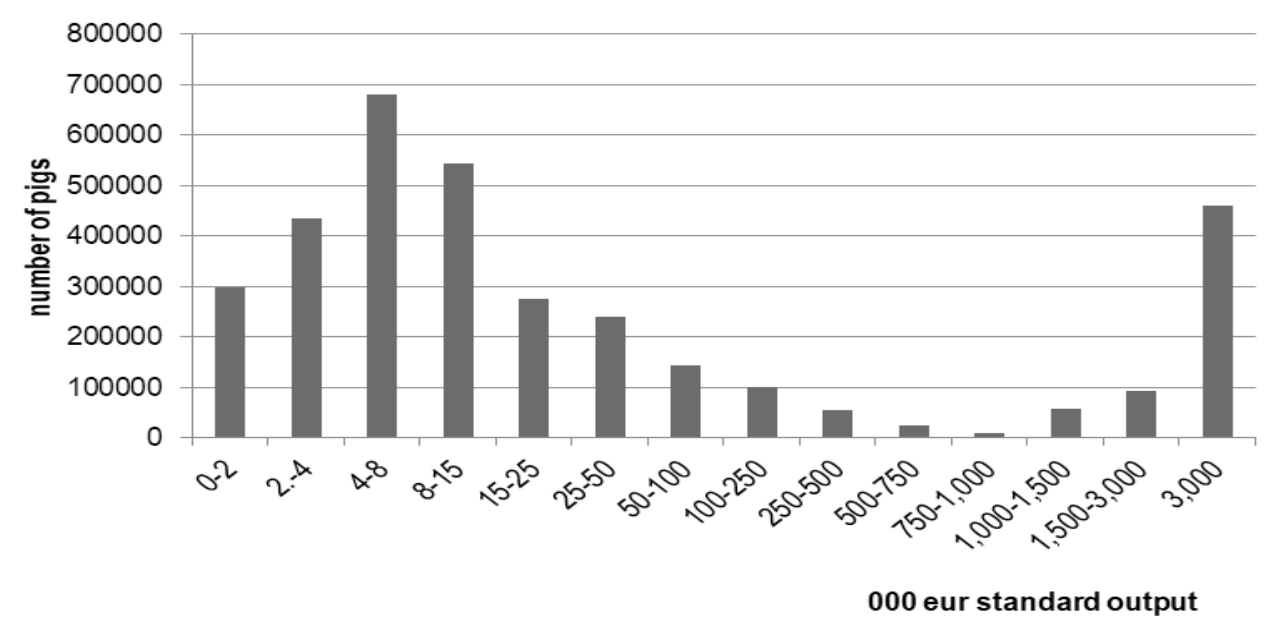

Republic of Serbia

Source: SORS, 2017

On the other hand, certain conclusions were obtained by examining the characteristics of the processing sector. In the analysis of processing sector the slaughtering industry was considered. According to MAEP data (2014) the total number of facilities for slaughtering and processing in Serbia in 2010 was 1,197. That indicates that Serbia has excessive slaughtering and processing capacity. As the facilities for slaughtering, cutting and processing are concerned, Serbia had 277 slaughterhouses for ungulates and 415 combined facilities (for slaughtering, cutting and processing). It is expected that with adoption of numerous domestic and European Union (EU) standards, the number of those facilities would be significantly reduced.

As the number of slaughtered fattening pigs is concerned, although there is a tendency of growing the number of pigs slaughtered in slaughterhouses (Figure 2.), slaughter of pigs on family farms for their own needs is still more widespread. 
Figure 2. The number of slaughtered pigs in Serbia

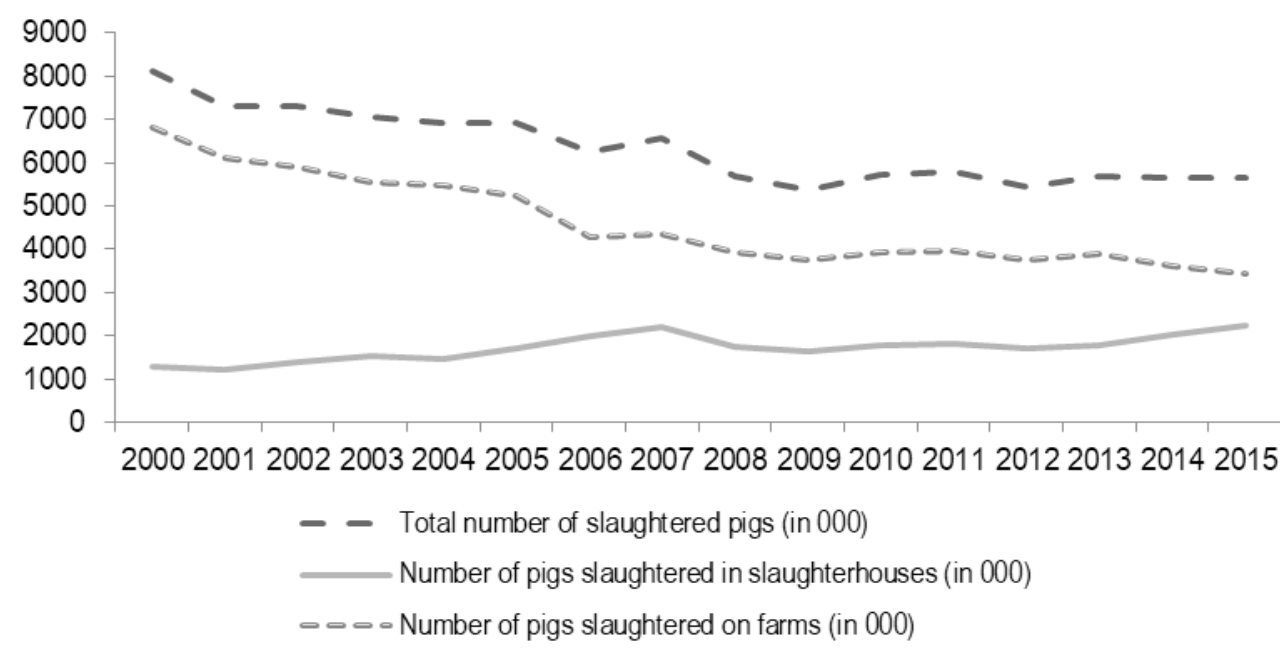

Source: SORS, 2017

Compared with EU countries, Serbia has similarities with countries that joined the EU after 2004. Namely Serbia is more similar to countries where pigs are slaughtered in places other than slaughterhouses ${ }^{9}$. Of the total number of pigs slaughtered in slaughterhouses, in the last 5 years, 70\% are slaughtered in 10 slaughterhouses (of which some are large and some are medium sized). That means that market structure of the processing sector can be considered as oligopsony. Also, due to the domination of several slaughterhouses located in certain areas, oligopsony is especially expressed in regional markets ${ }^{10}$.

Unlike other countries in which the process of internalization of the retail sectors started in the 1990s, in Serbia this process started later. After 2000 the structure of retail sector in Serbia changed and the participation of modern trade formats, such as hypermarkets and supermarkets increased significantly. On the other hand, the number of smaller

9 Although in a much smaller extent, compared to Serbia, in the EU except in slaughterhouses, slaughtering of livestock is also performed in places other than slaughterhouses. In 2014, $81.3 \%$ of slaughter outside the slaughterhouse was registered in countries that became members of the EU in 2004 or later. In 13 countries that have become the latest EU members (new members), $11.3 \%$ of the total number of slaughtered livestock make slaughter outside slaughterhouses. On the other hand, in the 15 countries that first became members of the EU (old members), this percentage is only $0.4 \%$. In general, there is a trend in the EU to reduce the number of livestock slaughtered in places other than slaughterhouses. Of the total number of livestock slaughtered in places other than slaughterhouses, the largest share refers to pigs $(62.3 \%)$, followed by sheep and goats (19.3\%) and cattle (18.4\%) (Eurostat, 2016).

10 Namely, as the transport and storage of livestock is very complicated and can lead to injury, death and high transport costs, producers in a small pig farms mostly decide to sell livestock to local slaughterhouses and finally are accepting their terms of purchase. 
trade facilities reduced. However, compared to other countries of Central and Eastern Europe, there is still relatively undeveloped trade in Serbia.

In the case of the retail sector, distribution of meat and meat products in Serbia is done through the following trade formats: super and hypermarkets, mini markets, specialized shops (butcher shop) and markets. In the past decade, the role of supermarkets has increased significantly. Although the role of supermarkets is growing, butcher shops still have a very important place in the meat distribution in Serbia. In the period from January to October 2014, the most important distribution channel for meat products with $23 \%$ share was supermarkets. A significant place with $21 \%$ share belongs to mini markets, traditional shops and butchers, while only $10 \%$ belongs to hypermarkets and cash \& carry facilities (Progressive magazine, 2015). As the distribution of meat and meat products are concerned, in relation to the EU countries Serbia has similarities with countries located in the south of the EU, since distribution is mostly done through traditional shops (Trienekens et al., 2009).

Figure 3 shows the dynamics of prices of participants in the pork supply chain in Serbia. It is evident that prices follow the same trend of movement on all three levels of the pork supply chain. Above average price growth for all three levels was achieved in the period August/September 2008. Namely, this rise in prices is mainly the result of a market failure that occurred in 2007. More exactly, large quantities of live animals import led to a low purchase prices of fattening pigs and because of that a large number of farmers slaughtered a significant number of fattening pigs and sows, which significantly reduced the supply of fattening pigs in 2008. Subsequently, the prices on all three levels of the chain are constantly falling, and below the average decline was realized in the period from June to August 2010. The price growth reappears in April 2012 and reaches its maximum in September of the same year. The main cause of the rise in prices of fattening pigs is the increase in animal feed prices. The second, significantly below the average fall in prices occurred in the period January/February 2015 due to the over-supply of fattening pigs on the domestic market. The main reason for market surpluses is the suspension of exports to Russia in late 2014 and the increase in imports of fattening pigs and pork from EU countries. Recovery of the price of fattening pigs, which passed on to other levels of the chain, occurred in April 2015 due to the delivery of fattening pigs to the Directorate for Commodity Reserves, and the resumption of exports to Russia. After that, due to surpluses that re-emerged on the market, the price of fattening pigs since September were falling again ${ }^{11}$.

11 Expecting further growth in exports to Russia, pig farmers decided to increase the number of fattening pigs. However, due to the re-suspension of exports on the one hand, and further growth of pork and fattening pigs import, on the other hand, prices of fattening pigs have started to decline again. 
Figure 3. Pork supply chain participants price dynamics

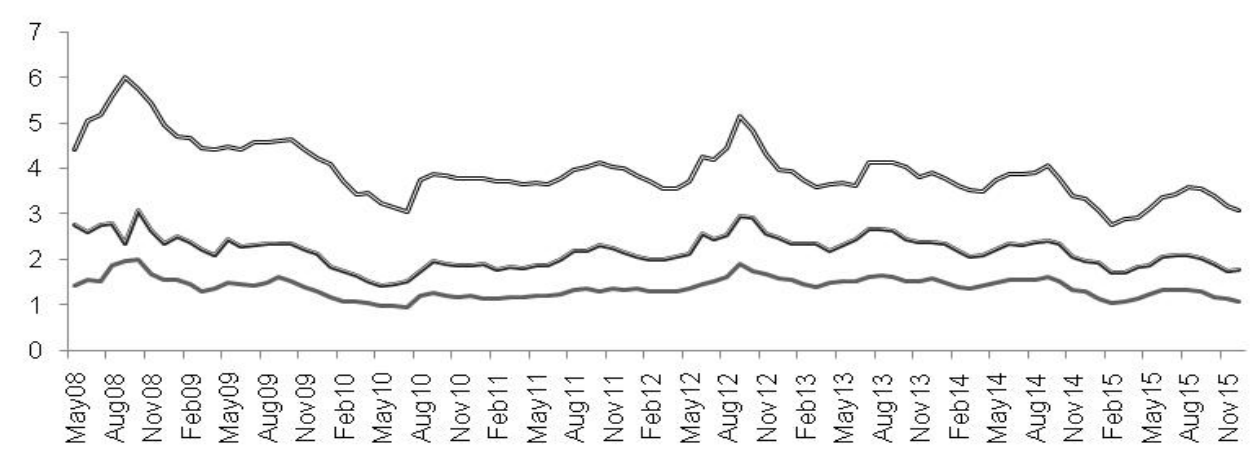

Note: pr - prices on the agricultural sector level; sl - prices on the processing sector level; $r$ prices on the distribution sector level.

Source: Monthly statistical bulletins; GEA info Centre.

\section{Estimation of the vertical price transmission}

The unit root test was used to test stationary and to determine the order of integration of variables. For the test of data series stationary the augmented Dickey Fuller, ADF, test was used. The results of the ADF test are shown in the following table. According to data in Table 1 the results of ADF test indicate that all variables are non-stationary and integrated of order 1.

Table 1. ADF test results

\begin{tabular}{|c|c|c|}
\hline Variable & I & II \\
\hline pr & -1.217571 & -1.019039 \\
\hline difpr & -6.206170 & -6.204973 \\
\hline sl & -1.022463 & -1.130119 \\
\hline difsl & -4.923578 & -4.975240 \\
\hline rl & -1.895142 & -1.886142 \\
\hline difrl & -6.950128 & -6.808618 \\
\hline
\end{tabular}

Note: I - with intercept, II - with intercept and trend, significance level 5\%

Source: Authors' calculations

Since the variables are integrated of order 1, the next step is the cointegration analysis between the variables. Namely, it is analyzed does the price data series have long run relationship, i.e. does the variables tend to the equilibrium relationship in the long run. The evaluation of cointegration was carried out using Johansen's cointegration rank test. Johansen's cointegration test includes two tests: a trace test and a maximumeigenvalue test. The following tables show the results of both tests. 
Table 2. Results of the cointegration analysis

\begin{tabular}{|c|c|c|c|c|c|c|}
\hline Eigenvalue & Trace st & $\begin{array}{c}\text { Critical } \\
\text { value }\end{array}$ & $\mathrm{p}$ value & $\begin{array}{c}\text { Max-Eigen } \\
\text { st }\end{array}$ & $\begin{array}{c}\text { Critical } \\
\text { value }\end{array}$ & $\mathrm{p}$ value \\
\hline 0.340287 & 53.63138 & 29.79707 & 0.0000 & 37.02352 & 23.131620 & 0.0002 \\
\hline 0.161393 & 16.64180 & 15.49471 & 0.0335 & 15.66511 & 14.264600 & 0.0298 \\
\hline 0.010913 & 0.97667 & 3.84147 & 0.3230 & 0.97667 & 3.841466 & 0.3230 \\
\hline
\end{tabular}

Source: Authors' calculations

Based on the data presented in the table of the threshold statistics and the maximum critical value test (Table 2.), it is evident that there is two cointegration equation among the analyzed series of price data, and therefore the application of the AECM model is considered justified. More precisely, it is evident that there is a long-term equilibrium relationship between the analyzed variables.

According to Vavra and Goodwin (2005) and Wohlgenant (2001), the largest number of authors estimate the vertical price transmission in upward direction. That is, the impact of the change in price at the level of the agricultural sector to the other participants of the chain is analyzed to a greater extent. However, according to Guillen and Franquesa (2010), most authors dealing with the analysis of price transmission in the market of fresh product consider that, changes in retail prices have a greater impact on price changes in the agricultural sector.

Therefore, in this paper, the direction of the estimation of the price transmission in the pork supply chain was "downstream". More specifically, the impact of the retail and processing sector price change on agricultural price change will be examined. Namely, in the period covered by the analysis of the price transmission, the changes that had occurred in the pork market had significant repercussions on pig farmers. Namely, because of the non-competitive purchase prices of the fattening pigs in the analyzed period the participants of the processing sector imported large quantities of fattening pigs and pork. Therefore, AECM model evaluated in this paper has the following form:

$\Delta \mathrm{pr}_{\mathrm{t}}=\alpha_{0}+\sum_{\mathrm{i}=1}^{\mathrm{M}} \beta_{1 \mathrm{i}}^{+}+\Delta \mathrm{sl}_{\mathrm{t}-1}+\sum_{\mathrm{i}=1}^{\mathrm{N}} \beta_{1 \mathrm{i}}^{-} \Delta \mathrm{sl}_{\mathrm{t}-1}^{-}+\sum_{\mathrm{i}=1}^{\mathrm{p}} \beta_{2 \mathrm{i}}^{+} \Delta \mathrm{rl}_{\mathrm{t}-1}^{+}+\sum_{\mathrm{i}=1}^{\mathrm{Z}} \beta_{2 \mathrm{i}}^{-} \Delta \mathrm{rl}_{\mathrm{t}-1}^{+}+$

$\sum_{\mathrm{i}=1}^{\mathrm{W}} \beta_{3} \Delta \mathrm{pr}_{\mathrm{t}-1}+\mathrm{y}^{+} \mathrm{ECT}_{\mathrm{t}-1}^{+}+\mathrm{y}^{-} \mathrm{ECT}_{\mathrm{t}-1}^{-}+\varepsilon_{\mathrm{t}}$

where $\Delta \mathrm{pr}_{\mathrm{t}} \Delta \mathrm{sl}_{\mathrm{t}}$ and $\Delta \mathrm{rl}_{\mathrm{t}}$ are the agricultural, processing and retail sector price changes, respectively; $\mathrm{ECT}_{\mathrm{t}-1}{ }^{+}$and $\mathrm{ECT}_{\mathrm{t}-1}{ }^{-}$are the lagged positive and negative residuals of the regression between $\mathrm{pr}_{\mathrm{t}}, \mathrm{sl}_{\mathrm{t}}$ and $\mathrm{rl}_{\mathrm{t}}, \Delta \mathrm{sl}_{\mathrm{t}}^{+}, \Delta \mathrm{sl}_{\mathrm{t}}^{-}, \Delta \mathrm{rl}_{\mathrm{t}}^{+}, \Delta \mathrm{rl}_{\mathrm{t}}^{-}$are segmented positive and negative changes of the processing and retail sector prices; $\beta^{+}{ }_{1 \mathrm{i},} \beta^{-}{ }_{1 \mathrm{i},} \beta^{+}{ }_{2 \mathrm{i}}, \beta^{-}{ }_{2 \mathrm{i}}, \beta_{3,}, \gamma^{+}, \gamma^{-}$ parameters of equation.

The results of the AECM are presented in Table 3. 
Table 3. Results of the AECM model

\begin{tabular}{|c|c|c|}
\hline Variable & Coefficient & Probability (p) \\
\hline$\alpha_{0}$ & -0.001940 & 0.8446 \\
\hline$\Delta \mathrm{sl}_{\mathrm{t}}^{-}$ & 0.281438 & 0.0001 \\
\hline$\Delta \mathrm{sl}_{\mathrm{t}-1}^{-}$ & 0.181873 & 0.0000 \\
\hline$\Delta \mathrm{sl}_{\mathrm{t}}^{+}$ & 0.168733 & 0.0000 \\
\hline$\Delta \mathrm{sl}_{\mathrm{t}-1}^{+}$ & 0.012172 & 0.7878 \\
\hline$\Delta \mathrm{rl}_{\mathrm{t}}^{-}$ & 0.191314 & 0.0000 \\
\hline$\Delta \mathrm{rl}_{\mathrm{t}-1}$ & 0.074631 & 0.0379 \\
\hline$\Delta \mathrm{rl}+{ }_{\mathrm{t}}$ & 0.213875 & 0.0000 \\
\hline$\Delta \mathrm{rl}{ }_{\mathrm{t}-1}$ & 0.075577 & 0.0943 \\
\hline$\Delta \mathrm{pr}_{\mathrm{t}-1}$ & -0.404549 & 0.0001 \\
\hline ECT- $_{t-1}$ & -0.456087 & 0.0007 \\
\hline $\mathrm{ECT}_{\mathrm{t}-1}$ & -0.051172 & 0.6600 \\
\hline $\mathrm{R}^{2}$ & \multicolumn{2}{|c|}{0.961953} \\
\hline DW & \multicolumn{2}{|c|}{1.927823} \\
\hline
\end{tabular}

Source: Authors' calculations

Since $\mathrm{p}=0.0429$ the zero hypothesis on the presence of symmetry $\left(\mathrm{H}_{0}: \gamma^{+}=\gamma-\right)$ in the long run was rejected, which means that the price transmission in the pork supply chain is asymmetric in the long run. The coefficient with $\mathrm{ECT}_{\mathrm{t}-1}^{-}$and $\mathrm{ECT}_{\mathrm{t}-1}^{+}$has an adequate sign. However, the probability of coefficient with $\mathrm{ECT}^{+}{ }_{\mathrm{t}-1}$ indicates that the estimated coefficient is not statistically significant. On the other hand, the value of the coefficient with $\mathrm{ECT}_{\mathrm{t}-1}^{-}$is statistically significant, which means that in the pork supply chain existed negative asymmetry in price transmission.

On the other hand, as $\mathrm{p}=0.0015$ the zero hypothesis on the presence of symmetry $\left(\mathrm{H}_{0}\right.$ : $\beta^{+}{ }_{1 \mathrm{i}}=\beta_{1 \mathrm{i}}^{-}$) in the transmission between the prices of the processing sector and the sectors of agriculture is rejected. That is, as the probability of the coefficient with $\Delta \mathrm{kc}_{\mathrm{t}-1}{ }^{+}$is greater than $5 \%$, the estimated coefficient is not statistically significant. This means that in the case of the relationship between the processing sector and the agricultural sector, negative asymmetry in transmission is present. That is, the fall in prices at the level of the processing sector is to a greater extent transferred to the agricultural sector than it is the case with price increase.

Also, by testing the zero hypothesis on the presence of symmetry in the transmission of prices between the retail sector and the agricultural sector, in the short term, it was found that transmission in the short term is symmetrical $\left(\mathrm{H}_{0}: \beta_{2 \mathrm{i}}^{+}=\beta_{2 \mathrm{i}}^{-}\right)$. In other words, as $p=0.2248$, the null hypothesis is accepted, which means that in the short run the fall and growth in the retail sector prices are both transferred to the agriculture sector. 
The most important factor influencing the change in prices is the change in supply and demand relations. In the analyzed period, on the pork market the biggest changes occurred as a consequence of the following factors:

- In the analyzed period, a large quantity of pork and live animals was imported.

- The export of pork and fattening pigs was limited in some countries, while in EU was prohibited.

- The largest number of large and medium-sized processors have their own facilities, and the lack of inputs which they need for further processing procure from import. Processors import large amounts of fattening pigs especially in the period when the price of fattening pigs on the domicile market is above the price in the international market.

\section{Conclusion}

As far as the main objective is concerned, it can be concluded that in Serbian pork supply chain negative asymmetry exists as a consequence of the slaughtering industry abuse of market power. More precisely, as a result of oligopsony market structure of the processing sector, it is possible to transfer the fall in prices on the agricultural sector faster than growth. Additionally, it is evident that there is no even distribution of profits among pork supply chain participants in Serbia.

The basic reason for processing sector abuse of market power is that during the observed period the movement of prices in the supply chain of pork was largely determined by trends in the domestic market. Namely, in the analyzed period, the import of large quantities of pork (especially from Spain) was allowed. On the other hand, the export was limited in some countries and completely banned in the EU countries because of vaccination against swine fever. Additionally, the most important category of in Serbia are small pig family farms that are not able to meet the needs of the slaughter industry with the quality and quantity of their product. Except that, a large number of meat processors in Serbia have their own facilities, and very often the lack of inputs are compensating from imports. Also, due to the absence of contracted production between the pig farmers and the processing sector, as well as due to the absence of organized purchase of agricultural products, it is evident that the meat processing sector has the possibility of abuse of market power by influencing the conditions of purchase and the manner of forming the purchase price.

It can be concluded that the position of small and medium-sized pig farms engaged in the pork supply chain is very unfavourable. Bearing in mind that the future movement of pork production in Serbia is determined by the production of these farms, it is necessary to find adequate ways to include them in complex relationships in the supply chain with pork. Also, it is necessary to find a mechanism that would prevent further abuse of market power by the processing sector either through organized purchase of fattening pigs or through contracted production with participants in the processing sector. 
Future research could be focused on the on the analysis of the institutional framework on impact on the price transmission in the pork supply chain. Also, it could be oriented to estimate the impact of agricultural policy measures, using the appropriate methodological framework, on the price transmission in the Serbian pork supply chain.

\section{Conflict of interests}

The authors declare no conflict of interest.

\section{References}

1. Abdulai, A. (2002). Using threshold cointegration to estimate asymmetric price transmission in the Swiss pork market. Applied Economics, 34(6), 679-687.

2. Bakucs, L. Z., \& Ferto, I. (2005). Marketing margins and price transmission on the Hungarian pork meat market. Agribusiness, 21(2), 273-286.

3. Blažková, I., \& Syrovátka, P. (2012). Price formation and transmission along the food commodity chain. Acta Universitatis Agriculrurae Et Silviculturae Mendelianae Brunensis, 15(4), 31-36.

4. Boyd, M. S., \& Brorsen, B. W. (1988). Price Asymmetry in the U.S. Pork Marketing Channel. North Central Journal of Agricultural Economics, 10(1), 103-109.

5. Čechura, L., \& Šobrova L. (2008). The price transmission in pork meat agri-food chain. Agricultural Economics, 54(2), 77-84.

6. Coleman, W., Grant, W., \& Josling, J. (2004). Agriculture in the new global economy. Northampton: Edward Edgar Publishing Inc.

7. Djurić, I., \& Petković, D. (2013). Vertical price transmission along the food supply chain: Serbian pork market". In D. S. Cvijanovic (Ed.): International Scientific Conference. Sustainable Agriculture and Rural Development in Terms of the Republic of Serbia Strategic Goals Realization within the Danube Region, Achieving regional competitiveness (pp. 298-313). Beograd.

8. Djuric, I., \& Puskaric, A. (2015). Impact of the Russian import bans the Serbian pork exports and prices. In: J. Subic, B. Kuzman, \& A. Jean Vasile(Ed.), Sustainable Agriculture and Rural Development in Terms of the Republic of Serbia Strategic Goals Realization Within the Danube Region, (pp. 173-188). Beograd.

9. ECORYS (2010). Study on the Competitiveness of the European Meat Processing Industry. Luxembourg: European Commission.

10. Eurostat (2016). Available at http://ec.europa.eu/eurostat/statistics-explained/extensions/ EurostatPDFGenerator/getfile.php?file=2001:4170:2000:1:0:0:0:31_1467653901_65. pdf, (referred on January, 2016).

11. GEA info Centar (2016). Gea center database. Beograd: Gea Centar.

12. Goodwin, B. K., \& Harper D. C. (2000). Price transmission, Threshold Behaviour, and Asymmetric Adjustment in the U.S. Pork Sector. Journal of Agricultural and Applied Economics, 32(3), 543-553. 
13. Guillen, J., \& Franquesa, R. (2010). Testing for market power in the Spanish meat market: Price transmission elasticity and asymmetry using econometric models. International Journal Computational Economics and Econometrics, 1(3/4), 294-308.

14. Holst, C., \& von Cramon-Taubadel, S. (2014). Trade, Market Integration and Spatial Price Transmission on EU Pork Markets following Eastern Enlargement. In: 54th Annual Conference, Goettingen: German Association of Agricultural Economists.

15. Houck, J.P. (1977). An approach to specifying and estimating nonreversible functions. American Journal of Agricultural Economics, 59, 570-572.

16. Jensen, J., \& Møller, A. S. (2007). Vertical price transmission in the Danish food marketing chain. Available at: http://citeseerx.ist.psu.edu/viewdoc/ download?doi=10.1.1.485.7809\&rep=rep1\&type=pdf (referred on January 2016)

17. Jeremic, M., Zekic, S., \& Matkovski, B. (2016). Economic characteristic of pig production in Serbia. Agroekonomika, 70, 11-18. [In Serbian: Jeremic, M., Zekic, S., \& Matkovski, B. (2016). Ekonomske osobenosti proizvodnje svinja u Srbiji. Agroekonomika, 70, 11-18.]

18. Karantininis, K., Katarkylidis, K., \& Persson M. (2011). Price transmission in the Swidish pork chain: asymmetric nonlinear ARDL. In: EAAE 2011 Congress Change and Uncertainty: Challenges for Agriculture, Food and Natural resources. The Hague: European Association of Agricultural Economists (EAAE).

19. Liu, X. (2011). Horizontal Price Transmission of the Finnish Meat Sector with Major EU Players. In: 2011 International Congress. Zurich; European Association of Agricultural Economists.

20. Meyer, A. (2004). Measuring market integration in the presence of transaction costs - a threshold vector error correction approach. Agricultural Economics, 31(2-3), 327-334.

21. Ministry of Agriculture and Environmental Protection Republic of Serbia (MAEP), (2014). Republic of Serbia IPARD Programme for 2014-2020. Available at: http:// www.minpolj.gov.rs/wp-content/uploads/datoteke/korisna_dokumenta/IPARD II_Program_ENG_05072017.pdf(referred on March, 2016).

22. Nestrov-Bizonj, J., Kovljenic, M., \& Erdelji, T. (2015). The Strategy for Agriculture and Rural Development of the Republic of Serbia in the Process of its Accession to the European Union. Strategic Management, 20(3), 57-66.

23. OANDA (2015). Average Exchange Rates. Available at OANDA: http://www. oanda.com/currency/average (referres Feb, 2016).

24. OECD (2006). Supermarkets and the Meat Supply Chain: The economic impact of food retailers on farmers, processors and consumers. Paris: OECD

25. Popovic, R. (2014). Livestock in the Republic of Serbia: Agricultural Census in 2012: Agriculture in the Republic of Serbia. Statistical Office of the Republic of Serbia, Belgrade. [In Serbian: Popovic, R. (2014). Stočarstvo u Republici Srbiji: Popis poljoprivrede 2012: Poljoprivreda u Republici Srbiji. Republički zavod za statistiku: Beograd.] 
26. Pjanić, M., Vuković, B. \& Mijić, K. (2018). Analysis of the Market Concentration of Agricltural Enterprises in AP Vojvodina. Startegic Management, 23(4), 40-45.

27. Progressive magazine (2015). Available at http://progressivemagazin.rs/online/ mesne-preradevine/ (referred on March, 2016).

28. Purcell, T. (1999). Forecasting Marketing Margins in the Australian pig industry. Annual Australian Agricultural and Resources Economics Society Conference. Christchurch

29. Rumankova, L. (2012). Time Series Properties and Their Influence on the Results of Price Transmission - Case Study of the Czech Pork Market. Available at: http://ageconsearch.umn.edu/bitstream/146284/2/agris_on-line_2012_4_special_ rumankova.pdf (referred on Jan, 2016).

30. Sanjuán, A. I., \& Gil, J. M. (1998). Price transmission analysis: A flexible methodological approach applied to European hog markets. In: 38 Congress of the European Regional Science Association. Vienna.

31. Statistical Office of the Republic of Serbia - SORS (2017). Available at http:// webrzs.stat.gov.rs/ (referred on Feb, 2017).

32. Statistical Office of the Republic of Serbia - SORS. Monthly Statistical Bulletin (6/2008.-2/2016): Available at http://www.stat.gov.rs (referred on Feb, 2017).

33. Trienekens, J., Petersen, B., \& Wognum, N., Brinkman, D. (2009). European pork chains: Diversity and quality challenges in consumer-oriented production and distribution. The Netherlands: Wageningen Academic Publisher.

34. Vavra, P., \& Goodwin, B. K. (2005). Analysis of Price Transmission along the Food Chain. OECD Food, Agriculture and Fisheries Papers, No. 3. Available at http:/www.oecd-ilibrary.org/agriculture-and-food/analysis-of-price-transmissionalong-the-food-chain_752335872456 (referred on Feb, 2017).

35. Von Cramon-Taubadel, S. (1998). Estimating asymmetric price transmission with the error correction representation: An application to the German pork market. European Review of Agricultural Economics, 25(1), 1-18.

36. Ward, R. W. (1982). Asymmetry in Retail, Wholesale and Shipping Point Prices for Fresh Fruits and Vegetables. American Journal of Agricultural Economics, 64(2), 205-212.

37. Wohlgenant, M. K. (2001). Marketing Marrgins: Empirical analysis. In: i. B. Rausser, Handbook of Agricultural Economics, Vol 1, pp. 934-970. Amsterdam: Elsevier Science B.V.

38. Wolffram, R. (1971). Positivistic measures of aggregate supply elasticities: some new approaches-some critical notes. American Journal of Agricultural Economics, $53,356-359$. 